\title{
Sistem Monitoring Alat Pemberi Pakan Ikan Otomatis Menggunakan NodeMCU Berbasis Internet of Things
}

Monitoring System for Automatic Fish Feeder Using NodeMCU Based on Internet of Things

\author{
Nifty Fath ${ }^{1}$, Reno Ardiansyah ${ }^{2}$ \\ ${ }^{1,2}$ Fakultas Teknik, Universitas Budi Luhur \\ E-mail: ${ }^{1}$ nifty.fath@budiluhur.ac.id ${ }^{1},{ }^{2}$ renosaputra4@gmail.com
}

\begin{abstract}
Abstrak
Budidaya ikan merupakan salah satu sektor yang dikembangkan untuk meningkatkan perekonomian di Indonesia. Salah satu permasalahan yang dijumpai oleh pembudidaya ikan adalah teknik pemberian pakan yang kurang efisien, misal harus dilakukan secara manual. Hal ini tentu saja akan kurang efisien apabila peternak memiliki banyak kolam yang harus dikelola dan memiliki pekerjaan sampingan, seperti mengelola sawah atau kebun. Oleh karena itu, penelitian ini menggabungkan konsep IoT dengan alat pakan ikan, khususnya ikan lele, sehingga peternak ikan tetap dapat memberikan pakan dari jarak jauh, di mana saja dan kapan saja serta dapat memonitoring sisa pakan ikan dengan tingkat akurasi sistem yang sangat baik. Modul NodeMCU digunakan sebagai mikrokontroler yang terintegrasi dengan modul wi-fi. Sistem monitoring dibuat menggunakan realtime database firebase. Sisa pakan dalam wadah penampung dapat terdeteksi oleh sensor ultrasonik. Berdasarkan hasil pengujian, diperoleh tingkat akurasi alat sebesar 96,8\%. Pengujian QoS yakni delay, throughput, packet loss, dan jitter terhadap komunikasi sistem monitoring menghasilkan nilai yang sangat bagus dan berindeks 4 berdasarkan standar TIPHON.
\end{abstract}

Kata kunci: pakan ikan otomatis, IoT, QoS, firebase

\begin{abstract}
Fish farming is one of the sectors developed to improve the economy in Indonesia. One of the problems encountered by fish farmers is the manual feeding technique. This will cause inefficiency if the farmer has a lot of ponds that must be managed and has a side job, such as managing rice fields or gardens. This study aims to combine the concept of IoT with fish feed equipment, especially catfish, into smart fish feeder with better acuracy. Therefore, fish farmers can still provide feed remotely, anywhere and anytime. Moreover, they can always monitor the fish feed. NodeMCU integrated with the wi-fi module is used as a microcontroller. The monitoring system is built using the Firebase realtime database. The remaining feed in the container can be detected by ultrasonic sensors. Based on the test results, the accuracy rate of the system was 96.8\%. QoS testing, such as delay, throughput, packet loss, and jitter on the monitoring system communication yields a very good value and indexed 4 based on the TIPHON standard.
\end{abstract}

Keywords: automatic fish feeder, IoT, QoS, firebase

\section{PENDAHULUAN}

Di Indonesia, budidaya ikan merupakan salah satu sektor yang dikembangkan untuk meningkatkan perekonomian nasional. Salah satu program prioritas yang dialokasikan oleh Kementrian Kelautan dan Perikanan adalah dukungan terhadap pengembangan budidaya lele. Sejak tahun 2015 hingga 2018, tercatat produksi perikanan budidaya lele mengalami peningkatan yang signifikan yakni sebesar 43\% [1]. Hal ini menunjukkan budidaya ikan di Indonesia, terutama budidaya ikan lele, memiliki potensi yang sangat baik. 
Dalam budidaya ikan lele, faktor pakan adalah faktor yang paling penting dalam menunjang keberhasilan budidaya yakni sekitar 60\% [2]. Oleh karena itu, dibutuhkan suatu pengelolaan yang efektif dan efisien. Beberapa permasalahan yang dijumpai oleh pembudidaya ikan adalah teknik pemberian pakan hewan yang kurang efisien, yakni tidak terukurnya jumlah pakan yang diberikan dengan tepat. Apabila pakan yang diberikan terlalu banyak, maka sisa pakan akan menjadi sumber bakteri sehingga meningkatkan peluang lele untuk mati. Saat ini, peternak memberi pakan ikan lele secara manual. Hal ini tentu saja akan kurang efisien apabila peternak memiliki banyak kolam atau memiliki pekerjaan sampingan, misal mengelola sawah atau kebun.

Beberapa penelitian mengenai pemberian pakan ikan otomatis telah banyak dilakukan, di antaranya penelitian yang dilakukan pada [3] dan [4]. Rancang bangun pemberi pakan ikan otomatis dengan sistem penjadwalan pada penelitan [3] memiliki ketepatan pemberian pakan sebesar 95,90\%. Penelitian pada [4] menggunakan Arduino dan aplikasi Blynk untuk mengatur keluarnya pakan ikan lele. Pada penelitian tersebut, terdapat error selisih berat pakan sebesar 5 gram. Komunikasi berbasis GSM dilakukan pada penelitian [5] untuk pemberian pakan ikan gurami secara otomatis.

Seiring dengan perkembangan teknologi, IoT juga banyak digunakan dalam pemberian pakan hewan otomatis, seperti yang dilakukan untuk peternak ikan [6], kucing [7], dan burung [8]. IoT merupakan sebuah konsep yang menghubungkan semua perangkat yang memiliki sensor dan saling terhubung dalam sebuah jaringan internet privat maupun publik [9]. Pada penelitian [6] dan [7], pemberian pakan hewan otomatis berbasis internet of things (IoT) menggunakan modul sensor berat untuk mengatur berat pakan yang diinginkan peternak ikan.

Oleh karena itu, pada penelitian ini, dirancang sebuah sistem pemberian pakan ikan lele otomatis menggunakan sebuah mikrokontroler NodeMCU ESP8266 yang telah terintegrasi dengan modul Wi-Fi berbasis IoT dan memiliki akurasi sistem yang lebih baik dari penelitian terdahulu. Dengan menggunakan sistem ini, peternak dapat memberikan pakan ikan darimana saja dan kapan saja serta dapat memonitoring pakan ikan yang tersisa pada wadah penampung.

\section{METODE PENELITIAN}

Perancangan sistem monitoring alat pemberi pakan otomatis terdiri dari dua bagian utama, yakni perancangan perangkat keras pemberi pakan otomatis dan perangkat lunak untuk sistem monitoring. Konsep yang digunakan untuk memonitoring sisa pakan adalah dengan sensor ultrasonik HC-SR04 yang lebih murah jika dibandingkan dengan sensor berat akan tetapi memiliki akurasi yang sangat baik. Sistem yang telah jadi diuji secara komprehensif baik dalam hal tingkat akurasi sistem dan quality of service dalam sistem komunikasi yang mengacu pada standar TIPHON [10].

\subsection{Perancangan Alat Pemberi Pakan Ikan Otomatis}

Perancangan sistem dimulai dengan membuat wadah tabung sepanjang $27 \mathrm{~cm}$ sebagai wadah pakan ikan. Sensor jarak HCSR-04 yang berfungsi untuk mendeteksi sisa pakan diletakkan pada tutup tabung bagian atas. Modul NodeMCU ESP8266 sebagai mikrokontroler digunakan untuk mengolah data menggunakan Arduino IDE. Hasil pembacaan sensor jarak oleh NodeMCU sinyal ke relay untuk menggerakkan motor DC. Proses buka dan tutup katup wadah pakan oleh relay digerakkan dengan motor DC. Rangkaian yang telah dirakit tersambung dengan catu daya AC 12 Volt 2 Ampere. Gambar 1 menunjukkan hubungan antar komponen perangkat keras.

Cara kerja dari alat pemberi pakan ikan otomatis adalah sebagai berikut. Katup pembuka yang terletak pada bagian bawah tabung wadah diatur terkopel dengan motor DC agar dapat berputar. Katup dapat berputar bersamaan dengan rotor motor DC. Untuk mengeluarkan pakan seberat 100 gram, diperlukan adanya delay motor DC selama $3500 \mathrm{~ms}$, sedangkan untuk mengeluarkan pakan sebesar 200 gram diperlukan delay motor selama 6500 ms. Nilai delay dari motor DC diperoleh berdasarkan percobaan. 


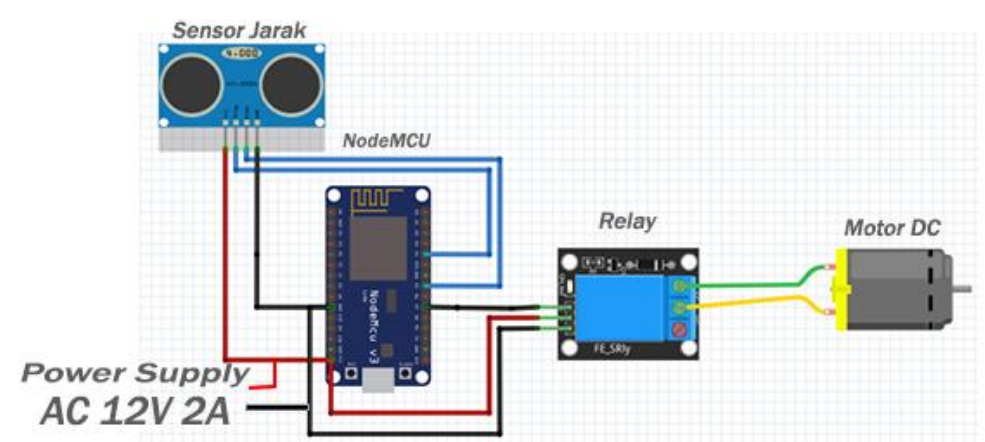

Gambar 1 Rancangan perangkat keras sistem pakan ikan otomatis

Sensor jarak yang terhubung oleh NodeMCU bertugas untuk mengukur jarak antara sensor dengan permukaan pakan sehingga dapat diketahui jumlah pakan yang tersisa. Hasil pembacaan sensor jarak berupa satuan panjang (centimeter) dikonversi ke dalam persen sisa pakan. Sebagai contoh, apabila hasil sensor jarak terbaca $0 \mathrm{~cm}$, maka dapat diartikan sisa pakan masih utuh $100 \%$. Apabila hasil sensor jarak terbaca $13,5 \mathrm{~cm}$, dengan kata lain setengah dari tinggi tabung, maka dapat diartikan pakan tersisa 50\%, dan seterusnya.

\subsection{Perancangan Sistem Monitoring Alat Pemberi Pakan Ikan Otomatis}

Sistem monitoring pakan ikan otomatis memiliki kontroler utama yaitu NodeMCU yang berfungsi sebagai pengolah data sensor dan antarmuka ke komputer. Pengolahan data pada mikrokontroler dirancang menggunakan software Arduino IDE yang nantinya akan dilanjutkan ke realtime database firebase.

Realtime database firebase adalah database yang terdapat pada host atau cloud. Data diolah dengan bahasa pemrograman JSON (JavaScript Object Notation) dan disinkronkan secara realtime ke setiap klien yang terhubung. Firebase menggunakan sinkronisasi data setiap kali data berubah sehingga semua perangkat yang terhubung akan menerima pembaruan data dalam waktu milidetik. Tampilan realtime database pada Google Firebase dapat dilihat pada Gambar 2. Pada gambar tersebut, terdapat parameter ping value dan motor value. Ping value adalah nilai yang dibaca dari sensor jarak yang terdapat dalam wadah pakan yang berfungsi untuk menunjukan sisa pakan dalam wadah secara realtime.

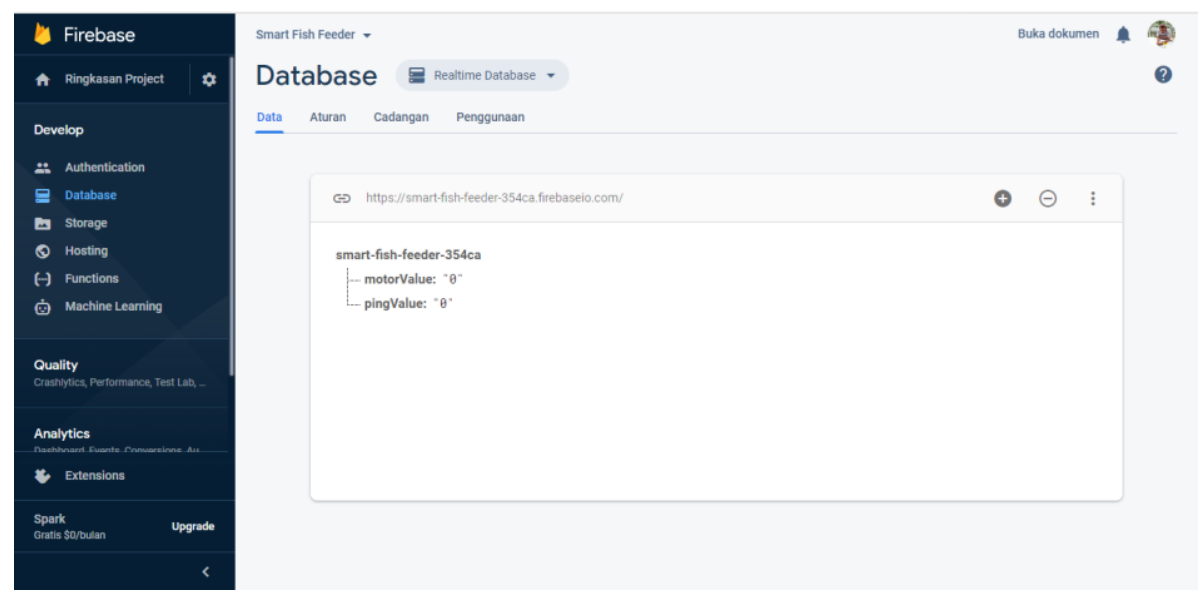

Gambar 2 Tampilan realtime database pada google firebase

Peternak dapat memberikan perintah untuk mengeluarkan pakan ikan dari jarak jauh. Diagram alir dari proses pengeluaran pakan ikan terlihat pada Gambar 3(a). Peternak hanya perlu memilih jumlah pakan ikan yang akan dikeluarkan pada aplikasi firebase. Pada penelitian ini, pilihan jumlah pakan ikan yang dapat dikeluarkan adalah 100 gram dan 200 gram. Data dari 
firebase kemudian dikirim ke modul NodeMCU melalui jaringan internet. Modul NodeMCU memberikan sinyal kepada relay untuk menggerakkan motor DC sesuai dengan masukan informasi jumlah pakan yang ingin dikeluarkan.

Setelah pakan ikan dikeluarkan sesuai dengan yang diinginkan, sensor jarak mengukur jarak terhadap batas permukaan pakan. Data berupa jarak tersebut kemudian dikonversi ke dalam persen sisa pakan wadah. Informasi sisa pakan wadah dikirim melalui NodeMCU melalui jaringan internet menuju aplikasi firebase sehingga peternak dapat membaca informasi sisa pakan secara otomatis. Tahapan untuk membaca informasi sisa pakan ikan sehingga dapat terbaca oleh peternak terlihat pada diagram alir Gambar3(b). Rangkaian sistem secara keseluruhan terlihat pada Gambar 4.

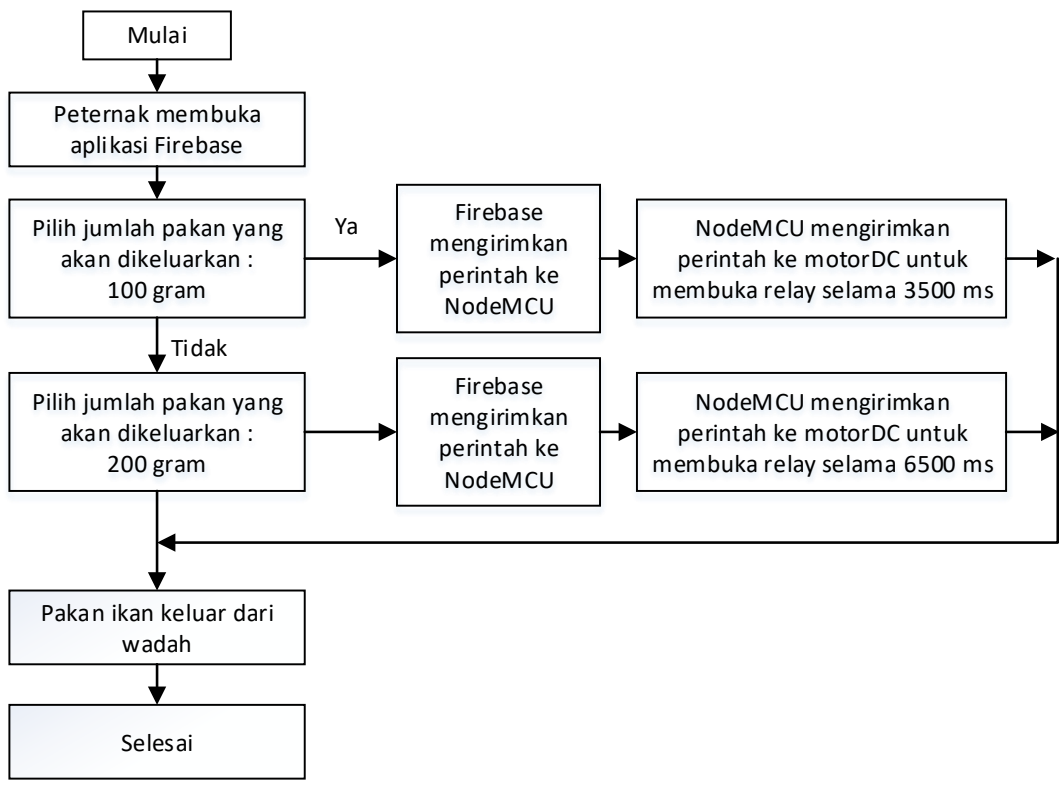

(a)

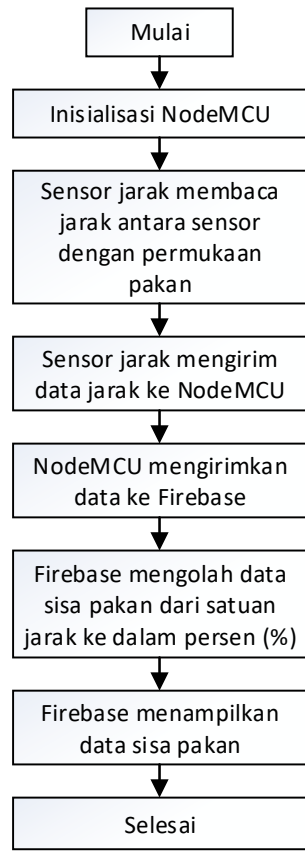

(b)

Gambar 3 Diagram alir (a) proses pengeluaran pakan ikan dan (b) proses pembacaan sisa pakan ikan

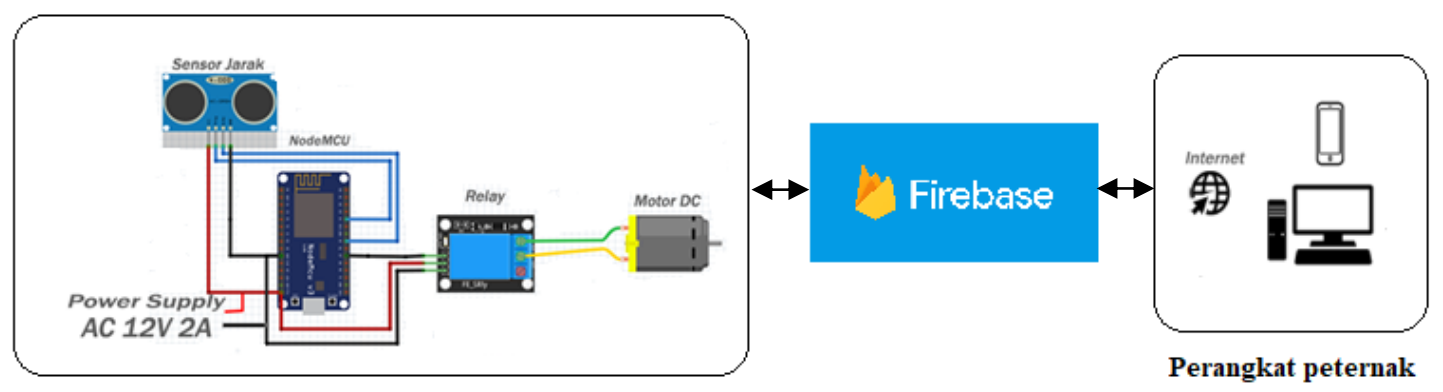

Alat pemberi pakan ikan otomatis

Gambar 4 Rangkaian sistem monitoring alat pemberi pakan ikan otomatis

\subsection{Tampilan Antarmuka Sistem Monitoring}

Tampilan antarmuka sistem monitoring terdiri dari dua tampilan utama, seperti yang terlihat pada Gambar 5. Tampilan utama menampilkan halaman utama berlogo kampus Budi Luhur dan mempunyai tombol 'START' untuk memulai aplikasi menuju tampilan kedua. Pada aplikasi, terdapat beberapa pilihan tombol yaitu 100 gram dan 200 gram. Pilihan dari tombol tersebut adalah pilihan untuk mengeluarkan jumlah takaran yang diinginkan oleh peternak. Selain itu, terdapat juga informasi mengenai sisa jumlah pakan yang terdapat pada wadah. 

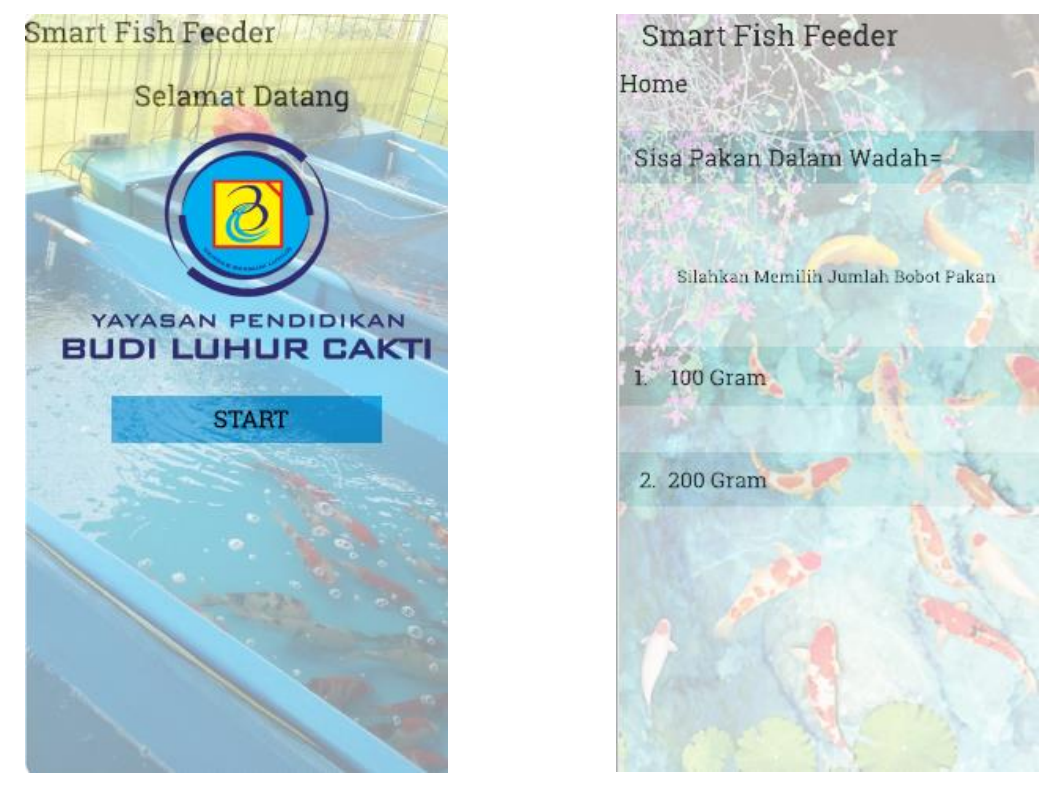

Gambar 5 Tampilan antarmuka aplikasi

\section{HASIL DAN PEMBAHASAN}

Beberapa pengujian dilakukan dalam penelitian untuk mengetahui kinerja sistem secara keseluruhan. Pengujian kinerja sistem terdiri dari pengujian alat pakan ikan otomatis dan pengujian QoS yang terdiri dari parameter delay, throughput, jitter, dan packet loss.

a. Hasil rangkaian alat pemberi pakan ikan otomatis

Berdasarkan diagram blok rancangan perangkat keras, rangkaian alat pemberi pakan otomatis dapat terlihat pada Gambar 6. Rangkaian tersebut dapat diletakkan di atas kolam ikan lele.

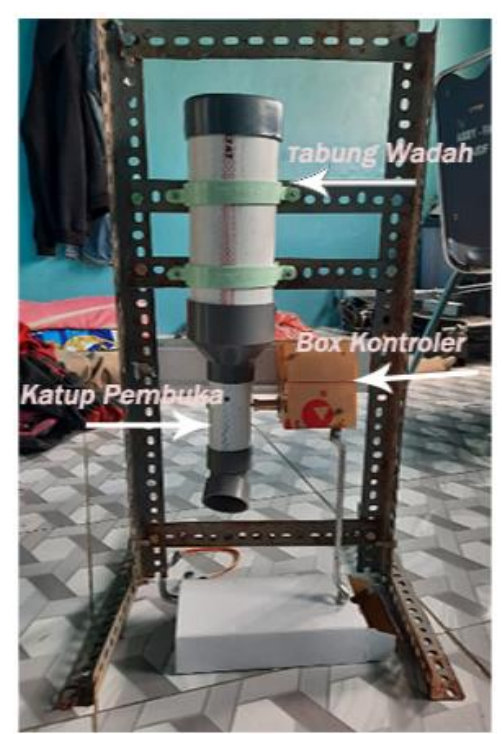

Gambar 6 Rangkaian alat pemberi pakan ikan otomatis

b. Pengujian sensor ultrasonik

Pengujian sensor ultrasonik HC-SR04 dilakukan untuk mengetahui akurasi hasil pembacaan jarak dari sensor ke permukaan pakan ikan. Hal ini akan berkatian dengan tingkat akurasi pembacaan sisa pakan ikan yang akan ditampilkan. Berdasarkan hasil pengujian yang 
terlihat pada Tabel 1, diperoleh rata-rata akurasi pembacaan sensor senilai 99,24\%.

Tabel 1 Hasil pengujian sensor ultrasonik

\begin{tabular}{|c|c|c|c|c|c|c|c|c|c|c|c|}
\hline $\begin{array}{c}\text { Jarak objek sesungguhnya } \\
(\mathrm{cm})\end{array}$ & 2 & 4 & 6 & 8 & 10 & 12 & 14 & 16 & 18 & 20 & 22 \\
\hline $\begin{array}{c}\text { Jarak berdasarkan } \\
\text { pembacaan sensor } \\
(\mathrm{cm})\end{array}$ & 2,02 & 4,1 & 6,03 & 8,02 & 10,0 & 12,01 & 14,03 & 16,20 & 18,2 & 20,21 & 22,10 \\
\hline
\end{tabular}

\subsection{Pengujian alat pakan ikan otomatis}

Pengujian alat pakan ikan otomatis bertujuan untuk mengetahui akurasi bobot pakan yang keluar dari wadah. Pengujian dilakukan pada jumlah pakan 100 gram dan 200 gram, dengan masing-masing 30 kali pengujian. Berdasarkan hasil pengujian dengan jumlah pakan yang diinginkan adalah 100 gram, terdapat error rata-rata jumlah pakan yang dikeluarkan sebesar 3,1\% seperti yang terlihat pada Tabel 2. Hasil pengujian alat dengan jumlah pakan yang diinginkan adalah 200 gram memiliki rata-rata error jumlah pakan yang dikeluarkan sebesar 3,2\%. Dengan kata lain, tingkat akurasi dari alat pakan ikan otomatis bernilai 96,8\%. Gambar 7 menunjukkan pakan ikan yang telah dikeluarkan pada pengujian 100 gram dan 200 gram.

Tabel 2 Hasil pengujian alat pakan ikan otomatis (pakan 100 gram dan 200 gram)

\begin{tabular}{|c|c|c|c|c|}
\hline \multirow{2}{*}{$\begin{array}{l}\text { Pengujian } \\
\text { ke- }\end{array}$} & \multicolumn{2}{|c|}{$\begin{array}{c}\text { Jumlah pakan yang diinginkan } 100 \\
\text { gram }\end{array}$} & \multicolumn{2}{|c|}{$\begin{array}{c}\text { Jumlah pakan yang diinginkan } 200 \\
\text { gram }\end{array}$} \\
\hline & $\begin{array}{l}\text { Jumlah pakan yang } \\
\text { dikeluarkan (gram) }\end{array}$ & Error & $\begin{array}{c}\text { Jumlah pakan } \\
\text { yang dikeluarkan } \\
\text { (gram) }\end{array}$ & Error \\
\hline 1 & 104 & $4 \%$ & 207 & $7 \%$ \\
\hline 2 & 106 & $6 \%$ & 205 & $5 \%$ \\
\hline 3 & 102 & $2 \%$ & 205 & $5 \%$ \\
\hline 4 & 109 & $9 \%$ & 208 & $8 \%$ \\
\hline 5 & 98 & $2 \%$ & 206 & $6 \%$ \\
\hline 6 & 99 & $1 \%$ & 209 & $9 \%$ \\
\hline 7 & 100 & $0 \%$ & 203 & $3 \%$ \\
\hline 8 & 100 & $0 \%$ & 204 & $4 \%$ \\
\hline 9 & 100 & $0 \%$ & 202 & $2 \%$ \\
\hline 10 & 100 & $0 \%$ & 200 & $0 \%$ \\
\hline 11 & 101 & $1 \%$ & 201 & $1 \%$ \\
\hline 12 & 101 & $1 \%$ & 199 & $1 \%$ \\
\hline 13 & 102 & $2 \%$ & 200 & $0 \%$ \\
\hline 14 & 102 & $2 \%$ & 198 & $2 \%$ \\
\hline 15 & 103 & $3 \%$ & 200 & $0 \%$ \\
\hline 16 & 103 & $3 \%$ & 202 & $2 \%$ \\
\hline 17 & 107 & $7 \%$ & 203 & $3 \%$ \\
\hline 18 & 103 & $3 \%$ & 205 & $5 \%$ \\
\hline 19 & 102 & $2 \%$ & 204 & $4 \%$ \\
\hline 20 & 107 & $7 \%$ & 204 & $4 \%$ \\
\hline 21 & 105 & $5 \%$ & 200 & $0 \%$ \\
\hline 22 & 108 & $8 \%$ & 201 & $1 \%$ \\
\hline 23 & 109 & $9 \%$ & 201 & $1 \%$ \\
\hline 24 & 103 & $3 \%$ & 204 & $4 \%$ \\
\hline 25 & 106 & $6 \%$ & 205 & $5 \%$ \\
\hline 26 & 107 & $7 \%$ & 203 & $3 \%$ \\
\hline 27 & 100 & $0 \%$ & 204 & $4 \%$ \\
\hline 28 & 100 & $0 \%$ & 204 & $4 \%$ \\
\hline 29 & 100 & $0 \%$ & 200 & $0 \%$ \\
\hline 30 & 101 & $1 \%$ & 204 & $4 \%$ \\
\hline
\end{tabular}




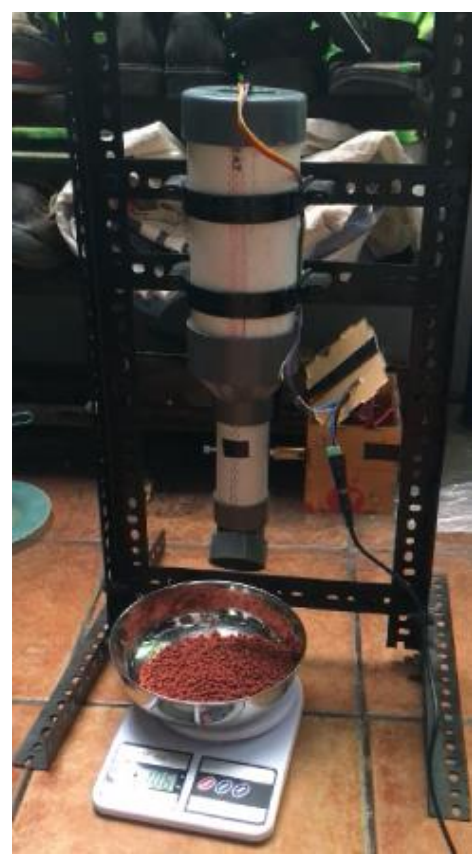

(a)

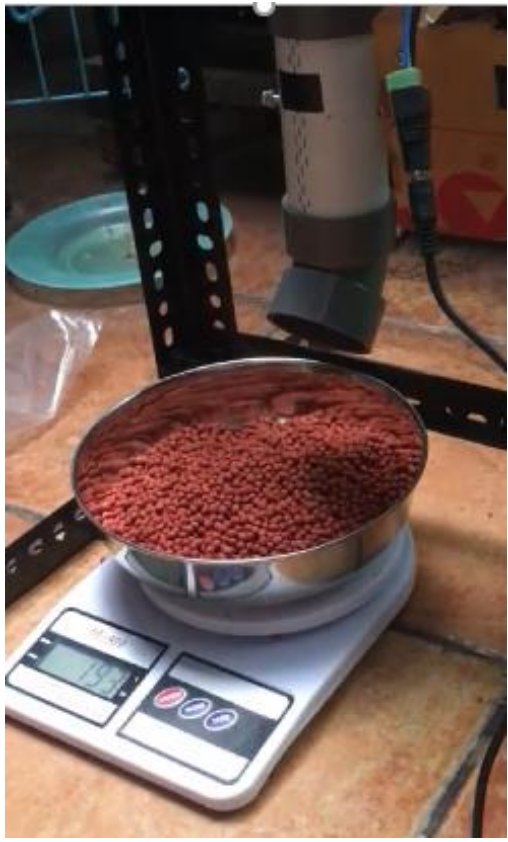

(b)

Gambar 7 Pakan ikan yang telah dikeluarkan pada saat memilih (a) 100 gram dan (b) 200 gram

c. Pengujian Quality of Service

Pengujian sistem komunikasi dan sistem monitoring dilakukan untuk mengetahui nilai QoS berupa delay, throughput, packet loss, dan jitter. Pengukuran dilakukan sebanyak 30 kali pengujian untuk setiap parameter QoS menggunakan perangkat lunak Wireshark. Standar TIPHON [10] digunakan dalam pengujian QoS.

\section{d.Pengujian Delay}

Pengujian dilakukan untuk mengetahui waktu delay dari transmisi data oleh NodeMCU ke Firebase. Perhitungan delay dari total paket yang dikirim pada waktu pengujian menggunakan persamaan 1. Gambar 8 menunjukkan hasil pengujian delay sebanyak 30 kali. Pengujian dilakukan pada pukul 07.30 - 10.30 untuk percobaan 1 - 15 dan pukul $15.00-18.00$ untuk percobaan 16 - 30. Rata-rata delay yang diperoleh dari 30 kali pengujian bernilai 3,09 ms. Berdasarkan standar TIPHON, rata-rata delay dalam pengujian masuk ke dalam kategori sangat bagus dan memiliki indeks 4 karena delay berada di bawah $150 \mathrm{~ms}$. Hasil pengujian yang fluktuatif dipengaruhi oleh kondisi jaringan pada saat proses pengiriman paket data dari alat hingga dapat terbaca oleh peternak.

$$
\text { Delay }=\frac{\text { Total waktu }}{\text { Total paket diterima }}
$$

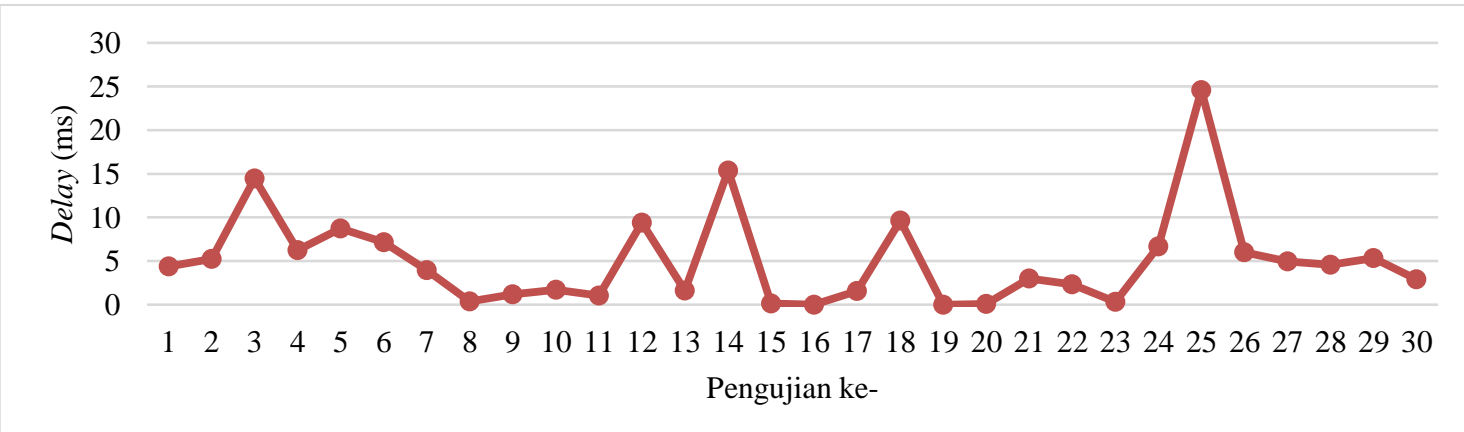

Gambar 8 Hasil pengujian delay 
e. Pengujian Throughput

Pengujian throughput dilakukan untuk mengetahui jumlah data (bit) yang dapat diterima dengan benar. Persamaan 2 digunakan untuk menghitung nilai throughput dalam satu kali pengujian. Hasil pengujian throughput terlihat pada Gambar 9. Rata-rata throughput dari 30 kali pengujian bernilai 2,48 kpbs. Berdasarkan standar TIPHON, kualitas komunikasi berdasarkan parameter throughput masuk ke dalam kategori sangat bagus dan memiliki indeks nilai 4 .

$$
\text { Throughput }=\frac{\text { Total paket diterima }}{\text { Durasi pengamatan }}
$$

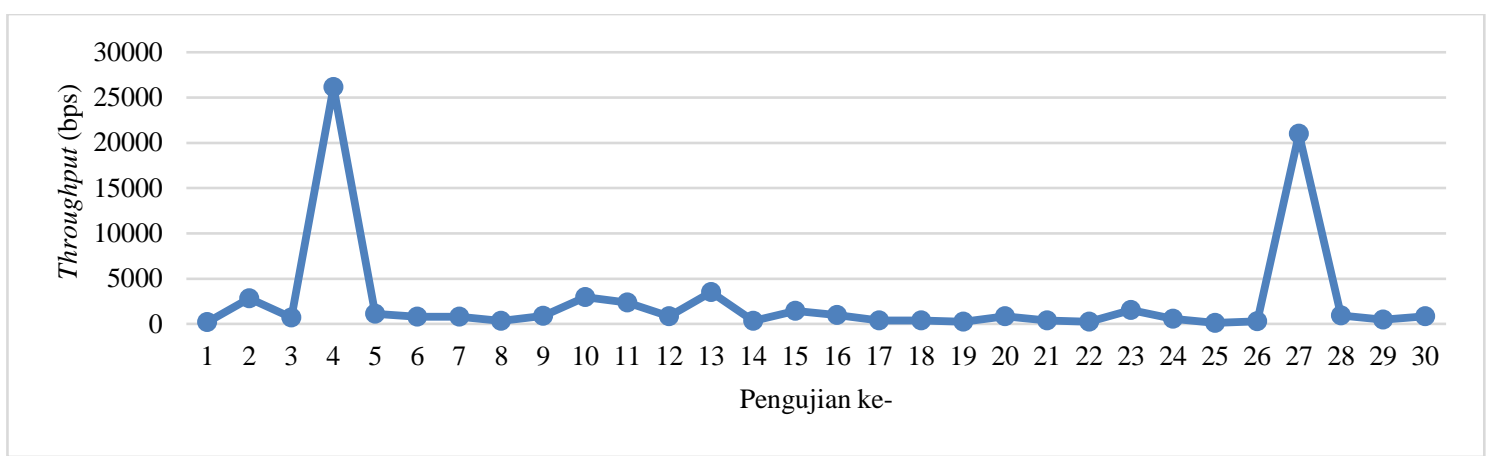

Gambar 9 Hasil pengujian throughput

\section{f. Pengujian Packet Loss}

Pengujian packet loss dapat dilakukan dengan memasukkan perintah tcp.analysis.lost_segment pada perangkat lunak Wireshark. Persamaan 3 digunakan untuk menghitung packet loss dalam satu kali pengujian. Hasil dari 30 kali pengujian packet loss terlihat pada Gambar 10. Dari keseluruhan hasil pengujian, packet loss bernilai 0\%, dengan kata lain tidak terdapat data yang hilang selama proses transmisi. Berdasarkan standar TIPHON, rata-rata packet loss pada pengujian termasuk ke dalam kategori sangat baik dan memiliki nilai indeks 4 .

$$
\text { Packet loss }=\frac{\text { Jumlah paket data dikirim-jumlah paket data diterima }}{\text { Jumlah paket data dikirim }} \times 100 \%
$$

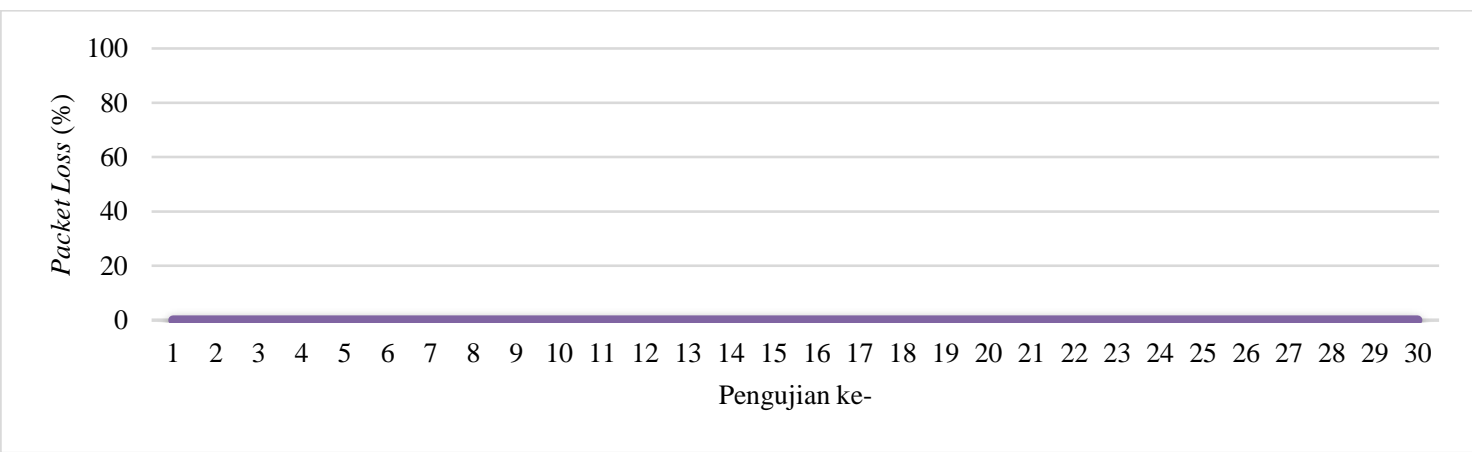

Gambar 10 Hasil pengujian packet loss

\section{i. Pengujian Jitter}

Pengujian nilai jitter dilakukan sebanyak 30 kali. Parameter jitter menunjukkan variasi delay yang diakibatkan oleh variasi jarak tempuh dari setiap paket data. Gambar 11 merupakan hasil perhitungan jitter dari 30 kali pengujian. Rata-rata jitter yang diperoleh adalah 0,63 ms. Berdasarkan standar TIPHON, nila rata-rata jitter pada pengujian masuk ke dalam kategori sangat bagus dan memiliki indeks 4 . 


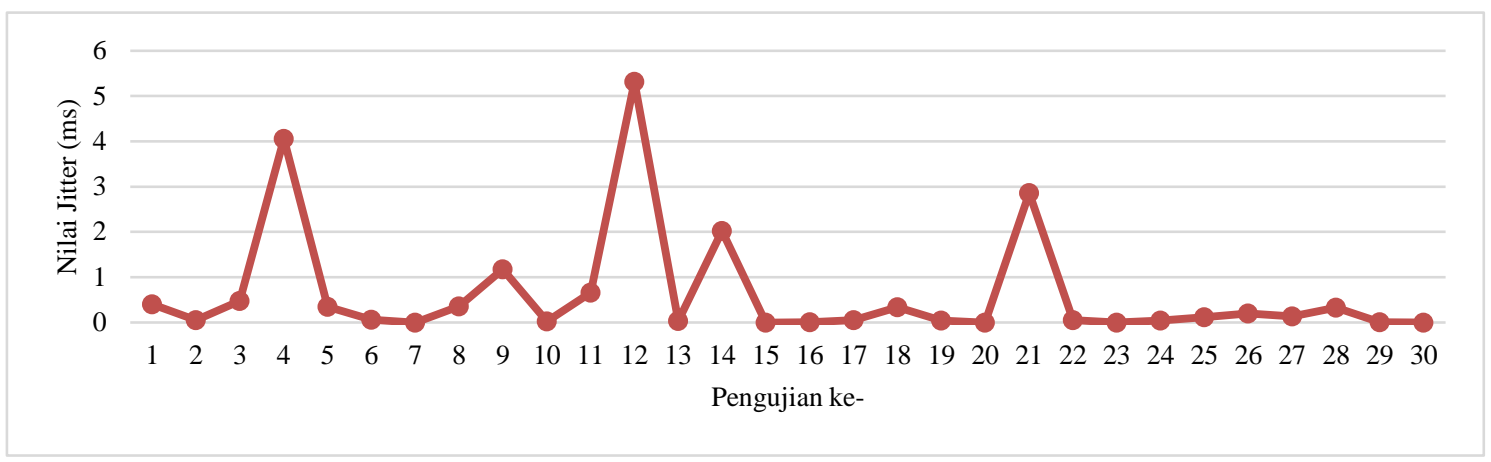

Gambar 11 Hasil pengujian jitter

\section{KESIMPULAN DAN SARAN}

Berdasarkan hasil pengujian yang telah dilakukan, terdapat beberapa hal yang dapat disimpulkan yakni sebagai berikut.

1. Sistem pemberi pakan ikan otomatis memiliki tingkat akurasi yang lebih baik dari penelitian terdahulu yakni 96,8\%.

2. Jumlah pakan ikan yang dikeluarkan dapat diatur melalui lama terbukanya katup yang terkopel dengan motor DC tanpa harus menggunakan sensor berat yang harganya relatif mahal.

3. Berdasarkan standar TIPHON, pengujian QoS dari komunikasi sistem monitoring termasuk ke dalam kategori sangat baik dan memiliki indeks 4 untuk pengujian delay, throuhgput, packet loss, dan jitter.

\section{DAFTAR PUSTAKA}

[1] D. J. P. Budidaya, "KKP Siapkan Program Prioritas 2019 untuk Perkuat Struktur Ekonomi Pembudidaya Ikan," 2019. https://kkp.go.id/djpb/artikel/9003-kkp-siapkan-programprioritas-2019-untuk-perkuat-struktur-ekonomi-pembudidaya-ikan (accessed Sep. 16, 2019).

[2] Lazuardi and H. Sudarto, "Pengaruh Pemberian Pakan dengan Dosis Berbeda Terhadap Pertumbuhan Benih Ikan Lele Sangkuriang," J. Ilm. Respati, vol. 8, no. 1, pp. 2-5, 2017, doi: $10.1038 / 132817 \mathrm{a} 0$.

[3] D. Prijatna, H. Handarto, and Y. Andreas, "Rancang Bangun Pemberi Pakan Ikan Otomatis," J. Teknotan, vol. 12, no. 1, pp. 30-35, 2018, doi: 10.24198/jt.vol12n1.3.

[4] Harifuzzumar, F. Arkan, and Ghiri Basuki Putra, "Perancangan Dan Impelementasi Alat Pemberian Pakan Ikan Lele Otomatis Pada Fase Pendederan Berbasis Arduino Dan Aplikasi Blynk," Pros. Semin. Nas. Penelit. Pengabdi. pada Masy., pp. 67-71, 2018.

[5] E. Alfianto, B. C. T A, and A. Sa'diyah, "Rancang Bangun Alat Pemberi Pakan Ikan Gurami Otomatis Dengan Memanfaatkan Gerak Rotasi," J. Ilm. Teknol. Inf. dan Robot., vol. 1, no. 2, pp. 17-21, 2019, doi: 10.33005/jifti.v1i2.17.

[6] Supriadi and S. A. Putra, "Perancangan Sistem Penjadwalan dan Monitoring Pemberi Pakan Ikan Otomatis Berbasis Internet of Thing," J. Apl. dan Inov. Ipteks SOLIDITAS, vol. 2, no. 1, pp. 33-41, 2019.

[7] K. Abdul and K. Wiajaya, "Rancang Bangun Alat Pemberi Makan dan Monitoring Sisa Pakan Kucing Berbasis Internet of Things ( Iot )," 2019.

[8] A. Hidayat, V. A. Wardhany, and A. Fahmi, "Sistem Pemeliharaan Burung Lovebird dalam Sangkar Berbasis IoT ( internet of things )," ELTEK, vol. 18, no. 1, pp. 9-14, 2020.

[9] M. A. Khan and K. Salah, "IoT security: Review, blockchain solutions, and open challenges," Futur. Gener. Comput. Syst., vol. 82, pp. 395-411, 2018, doi: 
10.1016/j.future.2017.11.022.

[10] ETSI, "Telecommunications and Internet Protocol Harmonization Over Networks (TIPHON); General aspects of Quality of Service (QoS)," Etsi Tr 101329 V2.1.1, vol. 1, pp. 1-37, 19nline]. Available: http://www.etsi.org/deliver/etsi_tr/101300_101399/101329/02.01.01_60/tr_101329v020 101p.pdf. 